\title{
Correction to: Characterization of bactericidal efficiency, cell selectivity, and mechanism of short interspecific hybrid peptides
}

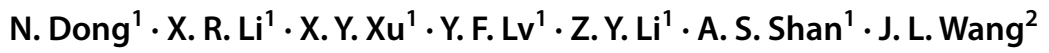

Published online: 12 May 2018

C) Springer-Verlag GmbH Austria, part of Springer Nature 2018

Correction to: Amino Acids (2018) 50:453-468

https://doi.org/10.1007/s00726-017-2531-1

In the Funding section, the first funding code " $41400172-4$ 15322" should be changed to "QC2015018".

The corrected funding section should be:

Funding We gratefully acknowledge the financial support from the Natural Science Foundation of Heilongjiang Province, China (QC2015018), the National Natural
Science Foundation of China (31472104, 31501914, and 31672434), the China Postdoctoral Science Foundation (2015M571385), the Postdoctoral Science Foundation of Heilongjiang Province, China (LBH-Z14026), the Special Financial Grant from the China Postdoctoral Science Foundation (2016T90267), and the Academic Backbone Project of Northeast Agricultural University (16XG14).

The original article can be found online at https://doi.org/10.1007/ s00726-017-2531-1.

A. S. Shan

asshan@neau.edu.cn

1 Laboratory of Molecular Nutrition and Immunity, Institute of Animal Nutrition, Northeast Agricultural University, Harbin, People's Republic of China

2 College of Animal Science and Veterinary Medicine, Jinzhou Medical University, Jinzhou, People's Republic of China 